\title{
20. STRUCTURAL HISTORY AND SIGNIFICANCE OF GABBROIC ROCKS IN THE UPPERMOST MANTLE: HESS DEEP, EPR (SITE 895) ${ }^{1}$
}

\author{
Lori A. Kennedy, ${ }^{2}$ Andreas K. Kronenberg, ${ }^{2}$ and Henry J.B. Dick ${ }^{3}$
}

\begin{abstract}
The close association of harzburgite, dunite, troctolites, olivine gabbro, and gabbro in the core recovered from the mantle exposed at Hess Deep suggests that these rocks belong to a suite of tectonized residual mantle peridotites through which a mafic melt was transported. Textures of this suite of rocks are interpreted to result from complex interactions between various igneous processes, including partial melting, multiple episodes of melt injection, wall-rock interactions and olivine crystallization. The undeformed nature of intergranular plagioclase, pyroxene and spinel in dunite containing deformed olivine grains suggests that crystallization of an interstitial mafic melt post-dates the high temperature deformation of olivine. Dislocation densities in olivine grains of troctolites are higher than those of olivine within harzburgites and dunites; thus the introduction of dislocations in the troctolites appears to correspond to a localized late-stage higher stress deformation that did not affect the harzburgites. Dislocation geometries and identification of the [100] Burgers vector for dislocations in olivine grains from the troctolites suggest that the introduction of dislocations occurred at relatively high temperatures; dislocations with the [100] Burgers vector are not activated under experimental conditions in olivine at temperatures below $800^{\circ} \mathrm{C}$. We suggest that the introduction of mafic melt within the dunites was responsible for the local high-stress event recorded by olivine grains, in contrast to the low stress deformation that may be expected for slow melt migration by percolation through porous dunites. Two rapid mechanisms of melt impregnation may have been responsible for this late-stage deformation: (1) the rapid introduction of melt by propagation of dikes in which the wall rock deforms in a visco-elastic manner, rather than by purely brittle processes, and (2) the rapid introduction of melt within dissolution channels. Crosscutting relationships of gabbros indicate that melt injection was episodic; this implies that troctolites continued to serve as pathways for melt which was extracted from below. The olivine gabbros possess two foliations: an early formed foliation may have resulted from the flow of partial melt while the latter foliation resulted from cataclastic deformation. The cataclastic deformation observed in the gabbros is probably due to rifting of the East Pacific Rise (EPR) lithosphere associated with the Cocos-Nazca propagator. Brittle deformation during rifting is highly localized within the mantle gabbros, suggesting that the gabbros were mechanically weaker than the surrounding peridotites.
\end{abstract}

\section{INTRODUCTION}

The mechanisms by which melt is extracted and transported through the mantle to the crust are complex and poorly understood. Experiments, theoretical modeling, and field observations suggest that upon formation of melt, gravity-driven compaction of the crystalline phases occurs, with diffuse upward migration of the buoyant melt phase (e.g., Sleep, 1974; Dick, 1977; Maaloe, 1981; McKenzie, 1984; Scott and Stevenson, 1986). Although this process is likely to govern small-scale melt migration throughout the upper mantle, geochemical and other evidence suggests that additional processes contribute to the transport of melt in the mantle, including (1) the propagation of dikes as a result of hydraulic fracturing (e.g., Fedotov, 1978; Maaloe, 1981; Spence and Turcotte, 1985; Nicolas, 1986, 1990; Ryan, 1988; Sleep, 1988; Ildefonse et al., 1993) and (2) the formation of dissolution channels that enable rapid extraction of melt without fracturing the country rock (e.g., Kelemen et al., 1995; Kelemen and Dick, 1995; Chadam et al., 1986). Melt migration by porous flow is a slow process and thus should not result in high stress deformation of the surrounding country rock. In contrast, dike propagation may be rapid and stresses within the surrounding host rock may be locally large. Models of dike propagation require a magmatic over-

'Mével, C., Gillis, K.M., Allan, J.F., and Meyer, P.S. (Eds.), 1996. Proc. ODP. Sci. Results, 147: College Station, TX (Ocean Drilling Program).

${ }^{2}$ Center for Tectonophysics and Department of Geology and Geophysics, Texas A\&M University, College Station, TX 77843, U.S.A. lak8931@venus.tam.edu

${ }^{3}$ Woods Hole Oceanographic Institution. Woods Hole, MA 02543, U.S.A. pressure for dike initiation, and most models examine dike propagation with a brittle process zone developed within the high stress, neartip region (e.g., Pollard, 1987; Spera, 1987). Propagation of dikes within hot mantle peridotites may potentially occur by visco-elastic processes. Rubin (1993) has examined the conditions for propagation of basaltic dikes within a host rock which exhibits essentially elastic behavior and time-dependent, visco-elastic behavior. Alternatively, porous flow may become unstable and result in the development of dissolution channels which localize flow and lead to melt migration that is also relatively rapid (Kelemen et al., 1995). Using both physical and numerical models, Kelemen et al. (1995) demonstrated that diffuse porous flow in a partially soluble medium is unstable and may become organized in discrete, high porosity channels. This model enables melt transport to occur at rates of $0.1-1 \mathrm{~m} / \mathrm{yr}$., much greater than rates of diffuse porous flow.

Field relationships, microstructural observations and geochemical analyses of mafic and ultramafic units from the upper mantle section of ophiolites provide evidence regarding the possible processes responsible for melt transport through the upper mantle to the crust. The transition from oceanic crust to mantle is gradational (e.g., Nicolas, 1990) and includes intercalated gabbroic dikes and segregations, troctolites, and dunite bodies. The intercalated nature of these rock types suggests that the processes of melt transport are complex and involve more than uniform flow of melt through a porous aggregate. Many recent studies suggest that some dunites observed at the Moho are not simple cumulates but rather are replacive in origin, having been formed as a result of pyroxene dissolution by a percolating mafic melt (e.g., Dick, 1977; Quick, 1981). If the melt is not completely extracted from the dunite, it may remain trapped and crystallize cli- 
nopyroxene and plagioclase along olivine grain boundaries or at triple junctions. As the amount of trapped melt is increased, small dikes and patches of olivine may be present in the dunite. Gabbro dikes associated with these dunites are termed "indigenous" by Nicolas (1986) and are thought to be formed from the same migrating melt that formed the dunites; the melt was not transported rapidly from a significant distance (e.g., Dick, 1977; Kelemen et al., 1995; Boudier and Nicolas, 1977; Nicolas, 1990). Field geometries of these indigenous dikes show that they do not root into feeder zones and they always exhibit haloes of dunite which replace harzburgites and other peridotites. Other dikes, termed "intrusive" by Nicolas (1986; 1990), appear to root into feeder zones and are thought to have formed during a crack propagation process. These intrusive dikes are not bordered by dunite; rather, they display chilled margins with the surrounding country rock suggesting that the melt probably had a more remote, high temperature source. Ceuleneer (1991) has reported evidence for slow percolation and rapid unstable flow near the transition zone of ophiolites, with porous flow accommodating melt transport at scales of $0.1-1 \mathrm{~m}$ and organized channel flow accommodating transport at larger length scales. Ceuleneer proposed that percolating melt may accumulate and that once a sufficient melt fraction is achieved, melt transport may occur rapidly by crack extension and melt injection.

Geochemical studies demonstrate that mid-ocean-ridge basalts (MORB) and shallow upper mantle peridotites are not in equilibrium with respect to trace elements (e.g., Salters and Hart, 1989; Johnson et al., 1990; Johnson and Dick, 1992). This indicates that chemical disequilibrium can be maintained during melt transport to the surface, implying that the transport of melt to the surface must be either rapid or localized within channels (e.g., Spiegelman and Kenyon, 1992; Nicolas, 1990; Kelemen et al., 1995), in apparent conflict with models of slow, diffuse, porous flow.

All three mechanisms of melt transport including porous flow, migration through discrete dissolution channels, and dike propagation may work in tandem. Porous and discrete channel flow of melt may dominate at great depths (e.g., $50 \mathrm{~km}$ ) where active melting occurs and an interconnected melt network is formed, leading to magmatic overpressuring, while hydrofracturing at shallow depths within the overlying peridotite leads to rapid extraction of melt (Nicolas, 1990).

Theoretical and physical models of melt transport and the mechanisms involved can only be assessed by direct observations of melt impregnated rocks generated at spreading centers. Mantle peridotites generated at a fast-spreading ridge were drilled for the first time during Ocean Drilling Program (ODP) Leg 147 at the Hess Deep. Intercalated sections of harzburgite, dunites, troctolites and gabbroic rocks were recovered and interpreted as representing sections through the Moho transition at the East Pacific Rise (Shipboard Scientific Party, 1993). At this location, upper mantle and lower crustal rocks are exposed on the seafloor due to tectonic opening of the Hess Deep. In this paper, we distinguish, based on microstructural observations, between the high temperature mantle deformation and a later, lower temperature, extensional brittle deformation. We further document the microstructures of the host peridotites, troctolites, and gabbroic rocks recovered during this leg in an effort to determine (1) the mechanisms of melt emplacement in the shallow mantle at the East Pacific Rise (EPR) and (2) the deformational history of the mantle gabbros in relation to the East Pacific Rise and the Cocos-Nazca rift.

We compare the deformation textures and foliations of the harzburgites, dunites, troctolites and gabbroic rocks recovered, as well as the dislocation substructures and dislocation densities of olivine grains within them, to evaluate the effects of melt introduction on the solid state deformation of the host rock. Foliations and optical microstructures, including grain shapes, recrystallized grains and subgrain walls record the processes of deformation and recovery to which the rock was subjected. These microstructures may be overprinted by later deformations or they may be eliminated by annealing. Of all microstructural features that record deformation, dislocation densities may change most readily in response to the last deformation. Dislocation densities are easily changed in a mineral by a small change in the magnitude of the local differential stress; furthermore, dislocation densities are relatively easily annealed at elevated temperatures, in the absence of significant deviatoric stress. The density of dislocations in minerals thus serves as a stress piezometer that is sensitive to the last stage of deformation of the solid. Dynamically recrystallized grains serve as piezometers as well; however, they change in size more slowly in response to a change in the deformation environment and hence grain sizes may not record stresses associated with low-strain, late-stage deformations. Determination of dislocation densities in olivine from melt-impregnated peridotites and harzburgites may help to resolve which mechanisms of melt migration were operative at the Hess Deep. If melt percolated through the country rock via porous flow at uniformly elevated temperatures, reductions in olivine dislocation density may be expected as a result of annealing. On the other hand, if rapid melt injection was involved which led to rapid deformation of the country rock, either in the region of a propagating crack tip or in compacting solids surrounding porous conduits to melt, increases in olivine dislocation densities may be expected.

\section{Hess Deep: Structural Setting}

The Hess Deep is the deepest part of a tectonically complex, westward-propagating rift valley located near the junction of the Cocos, Nazca and Pacific plates (Fig 1). Before approximately 1.3 Ma, the Hess Deep area consisted of a stable triple junction between the Cocos-Nazca Ridge and the EPR (Lonsdale, 1988). The rift valley has formed as a result of faulting associated with the westward-propagating Cocos-Nazca spreading center, which is currently opening up the eastern flank of young (0.5-1 Ma) EPR oceanic crust. A major intrarift ridge occurs between the Hess Deep and the northern scarp. The geology of the Hess Deep was investigated with two submarine dives in 1988 (Nautile) and 1990 (Alvin). From these dives, volcanic rocks, sheeted dikes, gabbros and peridotites were observed, although not as a continuous section (Francheteau et al., 1990; Karson et al., 1992). Transects along eastern and western sections of the Hess Deep indicate that there is no lateral continuity between the rock types. Based on these observations, Francheteau et al. (1990) proposed two models for the uplift of the Hess Deep; one requires serpentine diapirs and high angle faults to accommodate uplift, whereas the other infers uplift accommodated by low-angle detachment faults, similar to those mapped in continental metamorphic core complexes and recently postulated to exist at slow spreading centers (Dick et al., 1991; Dick et al., 1981; Karson et al., 1987). Optical microscopy of the Hess Deep peridotites has revealed an absence of widespread deformation of serpentine. The absence of local serpentine deformation from the peridotites does not support the model invoking a diapiric uplift for the Hess Deep mantle (Shipboard Scientific Party, 1993). Furthermore, an extension model for the formation of the Hess Deep is supported by restored orientations of veins and magmatic foliations (MacLeod, Boudier, et al., this volume) and by paleomagnetic data from Hole $895 \mathrm{E}$ (Kelso et al., this volume).

\section{Site 895: Background}

Site 895 is located at the southern slope of the intrarift ridge, where, based on previous Nautile and Alvin dives, peridotites are known to outcrop. Six holes were drilled at this site; the most significant recoveries were from Holes $895 \mathrm{D}$ and $895 \mathrm{E}$. Despite the proximity of Hole 895E to Hole 895D (Hole 895E is located about $270 \mathrm{~m}$ 


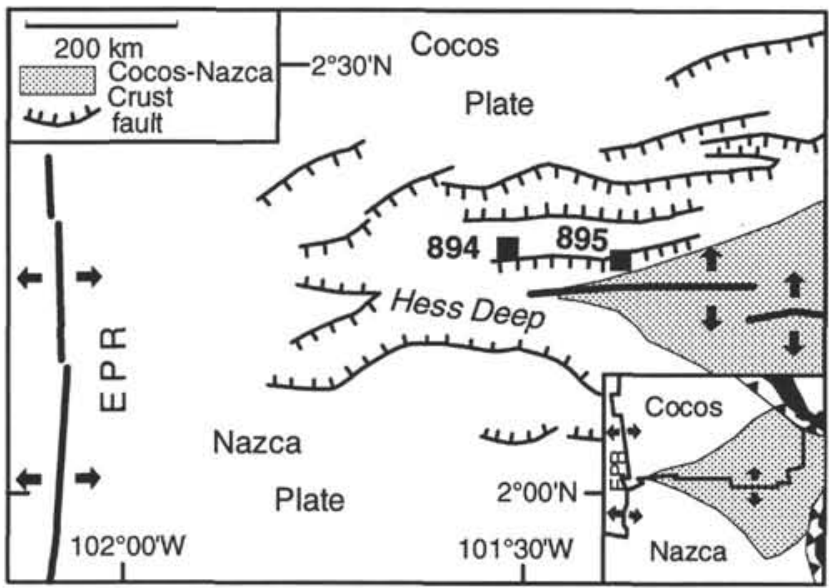

Figure 1. Location of the Hess Deep, showing site locations. Site 894 recovered gabbroic rocks; Site 895 recovered peridotites and mafic rocks (after Lonsdale, 1988).

north of Hole 895D), the stratigraphy of these holes is very different, even when block rotations and local slumping are taken into account. The upper portion of Hole $895 \mathrm{D}$ consists primarily of harzburgite, and the lower half is made up of an intercalated mixture of harzburgite, dunite, and gabbroic rocks (olivine gabbros, gabbros, and troctolites; Fig. 2A). In contrast, Hole $\mathrm{E}$ is composed predominantly of dunite, with more gabbroic rocks present than harzburgite (Fig. 2B),

The lateral variability of rock types in this region suggests that the upper mantle at the Hess Deep is extremely heterogeneous. Furthermore, the close association of dunite, harzburgite and gabbroic rocks in Hole $895 \mathrm{E}$ as well as the petrology and textures of these ultramafic and mafic rocks suggest that these rocks may be products of melt migration, reactions between melts and wall-rock and olivine crystallization close to the mantle/crust boundary (e.g., Dick and Natland, this volume; Allan and Dick, this volume)

\section{ANALYTICAL METHODS}

Deformation microstructures were observed both in plane light and between crossed polars by conventional optical microscopy. Dislocations in peridotites were decorated by oxidation of olivine by heating samples in a furnace at $900^{\circ} \mathrm{C}$ for $1 \mathrm{hr}$ (Kohlstedt et al., 1980). This procedure results in nucleation of iron oxide on dislocation pits and lines that can be detected by optical microscopy. As shown by Kohlstedt et al. (1980), the 1-hr heating period is insufficient to alter dislocation densities or configurations. Transmission electron microscopy (TEM) was performed using a JEOL 2010 operated at 200 $\mathrm{kV}$ and a Philips 400T operated at $120 \mathrm{kV}$. Dislocation densities for the decorated thin sections of known thickness were determined by measuring the number of intersections for a given volume (Hirsch et al., 1965). Dislocation densities were determined from TEM foils by measuring the number of dislocations within a given area (by counting their intersections with the top and bottom of the foil, and dividing by a geometric factor appropriate for a random distribution of line orientations; Hirsch et al., 1965).

Experiments show that steady-state densities of dislocations in olivine are a function of stress and are independent of temperature, strain rate and other environmental parameters (Durham et al., 1977). Following deformation, a reduction in the number of dislocations may occur by a number of processes including the annihilation of dislocations of opposite sign and climb of dislocations into subgrain or grain boundaries.

\section{DEFORMATION AND MELT IMPREGNATION FABRICS}

\section{Ultramafic Rocks}

The ultramafic rocks recovered at Site 895 appear to represent a suite of tectonized residual mantle peridotites that have been locally impregnated by and reacted with a mafic magma after a high temperature, low stress deformation (Shipboard Scientific Party, 1993). Ultramafic rocks recovered at Site 895 display fabrics similar to those observed in the mantle sections of ophiolites (e.g., Nicolas, 1989); hence, their deformation has been interpreted to have occurred at the high temperature conditions of the asthenosphere (Boudier et al., this volume). The harzburgites have a steeply dipping foliation (Boudier et al., this volume), which is defined by the elongation of spinel and orthopyroxene. These rocks are porphyroclastic in texture; orthopyroxene porphyroclasts $(2-5 \mathrm{~mm}$ in diameter) exhibit tilt subgrain boundaries perpendicular to the (100) slip plane and they are surrounded by polygonal recrystallized orthopyroxene grains $(0.5-1$ $\mathrm{mm}$; Fig. 3A). Despite the poorly developed grain-shape fabric of olivine grains, U-stage measurements indicate that they have a strong crystallographic preferred orientation (Boudier et al., this volume). Where they are not heavily altered, olivine grains have curved grain boundaries, meeting at simple triple junctions (Fig. 3B). Tilt boundaries in olivine are rare; however, where they are present, they are subplanar and widely spaced. All of these observations imply a high degree of recovery of defects in the crystal lattice. Harzburgite grades from moderately enstatite-rich $(20.3 \% \mathrm{EN})$ to enstatite-poor $(7.3 \%$ EN), while dunite rarely contains more than trace amounts of enstatite. While a complete gradation in pyroxene content between the two may exist, there is a clear bimodal population distribution, with most dunites containing close to $100 \%$ olivine with only accessory spinel and trace amounts of orthopyroxene, diopside and plagioclase. Transitions from relative pyroxene-rich harzburgite to near pyroxene-absent dunite typically occur over intervals of a few centimeters or less. Contacts between these rock types may be gradational or sharp; where contacts are sharp, they are subvertical to steep in orientation $\left(50^{\circ}-70^{\circ}\right)$ and no clear chill margins are apparent.

Although many isolated dunites occur within the harzburgite tectonite, most are associated with troctolites, olivine gabbros, gabbros, and gabbronorites, particularly those from Hole $895 \mathrm{E}$. A weak foliation, marked by the alignment of elongate spinel grains, is present in the dunites. The dunites are heavily serpentinized; commonly greater than $95 \%$ of the olivine is altered (Früh-Green, Plas, and Lécuyer, this volume). Despite the intense alteration, grain boundaries are still recognizable. Relict olivine grains $(2-5 \mathrm{~mm}$ in diameter) are curved, meeting at triple junctions and sharp subgrain boundaries are rare. The presence of strained olivine grains indicates that a portion of the Site 895 dunites is likely of residual mantle origin and does not represent cumulates. Troctolites display gradational contacts with dunites. Clinopyroxene and plagioclase are found at olivine triple junctions and along grain boundaries, imparting a nearly poikilitic texture to these rocks with increasing modal abundance. Depending on the concentrations of mafic components, plagioclase and clinopyroxene may form irregular patches or interconnected networks and local segregations that make up $30 \%-40 \%$ of the rock (Fig. 4). Unlike olivine, these minerals do not display a high-temperature deformation texture; rather, plagioclase and clinopyroxene are commonly undeformed and occasionally display only undulatory extinction (Fig. $3 \mathrm{C})$. Unaltered contacts between the interstitial mafic minerals and olivine grains are rare. More commonly a reaction rim of chlorite occurs between plagioclase and olivine (Fig 3D). There is no shape fabric developed in the troctolites, with the exception of one weakly foliated plagioclase dunite in contact with an unfoliated olivine gabbro. 
A

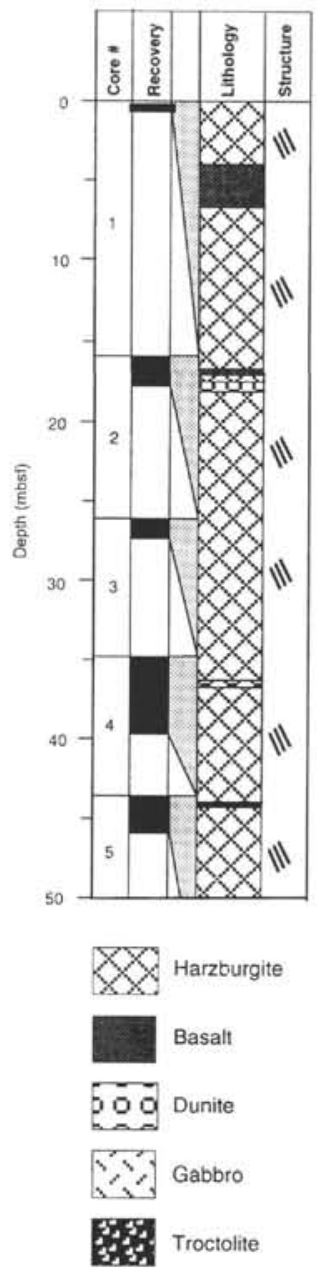

Hole 895D

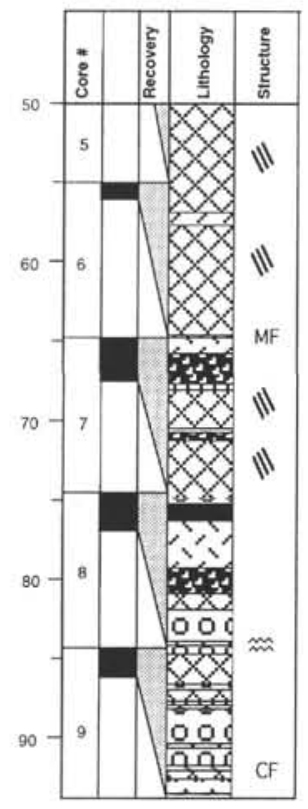

Viv Dunite-Troctolite-Gabbro-Harzburgite

$\therefore$ Olivine gabbro

(II : High Temperature Foliation

MF : Magmatic Foliation

$\approx$ : Sheared Contact

CF : Cataclastic Foliation
B

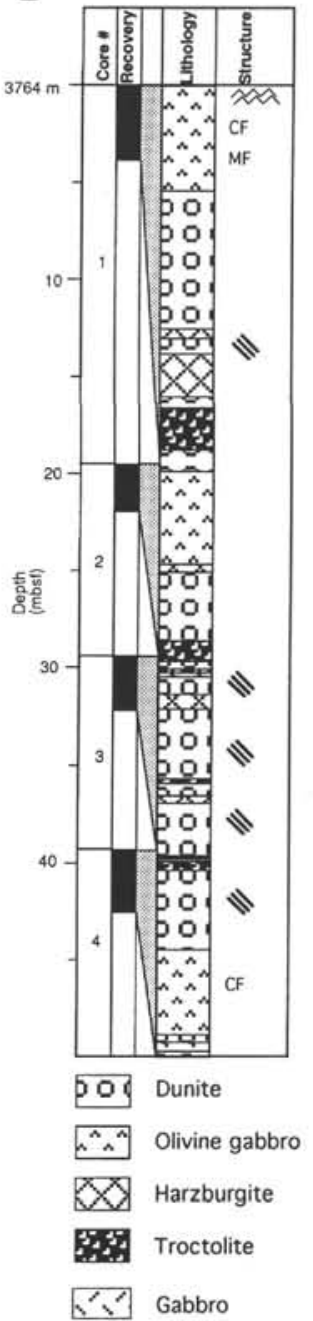

Hole 895E

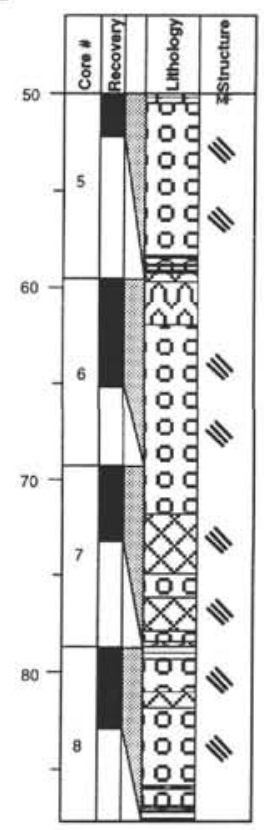

Figure 2. A. Lithostratigraphy and location of sheared contacts for Hole 895D. B. Lithostratigraphy and location of sheared contacts for Hole 895E.

The dislocation densities and substructures of olivine vary considerably within an individual grain, and from grain to grain in any given thin section. This observation holds true for olivine from harzburgites, dunites, plagioclase-dunites and olivine gabbros, although it is particularly pronounced in the troctolites. Dislocation geometries observed in olivine from iron-oxide stained harzburgites and dunites indicate that deformation occurred at high temperatures and low stresses with clear evidence of recovery. (100) tilt boundaries which result from activation of the $\{0 \mathrm{kl}\}<100>$ slip system (the predominant high temperature slip system in olivine) are apparent, but generally are not well formed. Dislocation loops with geometries that reflect glide from a common source, dislocation helices and free dislocations are present (Fig. 5A). Glide loops are abundant (Fig. 5B). Many grains are nearly devoid of dislocations.

TEM observations of well-annealed olivine grains from harzburgite show tilt walls and rare, free dislocations (Fig. 5C). TEM observations of olivine grains of harzburgite which exhibit undulatory extinction and grain elongation, show the presence of long segments of screw dislocations. Optically determined olivine dislocation densities for olivine grains from harzburgite average at $\sim 7.8 \times 10^{3} \mathrm{~mm}^{-2}$, while the highest measured dislocation density was $2.3 \times 10^{4} \mathrm{~mm}^{-2}$ (Fig. 6A). TEM-determined olivine dislocation densities for olivine grains from harzburgite reach $\sim 1.7 \times 10^{6} \mathrm{~mm}^{-2}$. Assuming that dislocation densities scale with stresses during deformation, we used the relationship between differential stress and dislocation density as ex- pressed by Kohlstedt et al. (1980) to estimate shear stresses from TEM-determined mean dislocation densities of $\sim 65 \mathrm{MPa}$ for harzburgites. However, dislocation densities in olivine grains from these rocks vary widely and point counts along traverses spaced 1 $\mathrm{mm}$ apart show that $18 \%$ of olivine grains from harzburgites are nearly devoid of dislocations and $4 \%$ had dislocations densities that were too high to count by optical methods.

In contrast to the dislocation substructures of olivine grains from the harzburgites, evidence for the operation of recovery processes from olivine grains in troctolites is not as apparent. Dislocations in olivine grains from these rocks are aligned and far more dense (Fig. 5D). Furthermore, in the troctolites, olivine grains devoid of dislocations are extremely rare. Average olivine dislocation densities determined optically for troctolites are on the order of $1.8 \times 10^{4} \mathrm{~mm}^{-2}$ (Fig. $6 \mathrm{~B})$. However, dislocation densities greater than approximately $3 \times$ $10^{4} \mathrm{~mm}^{-2}$ were difficult to measure accurately by optical methods and this average density is probably lower than the true mean. Thus, $26 \%$ of grains from the troctolites have dislocation densities too high to count, compared to $4 \%$ for olivine grains from harzburgites. Moreover, in contrast to olivine grains from harzburgites, less than $1 \%$ of olivine grains from troctolites are free of dislocation.

Transmission electron microscopy (TEM) analysis of the troctolites reveals the presence of long segments of screw dislocations and short edge dislocations (Fig. 5E, F). The Burger's vector for the screw dislocations in Figure 5F has been identified as [100], charac- 

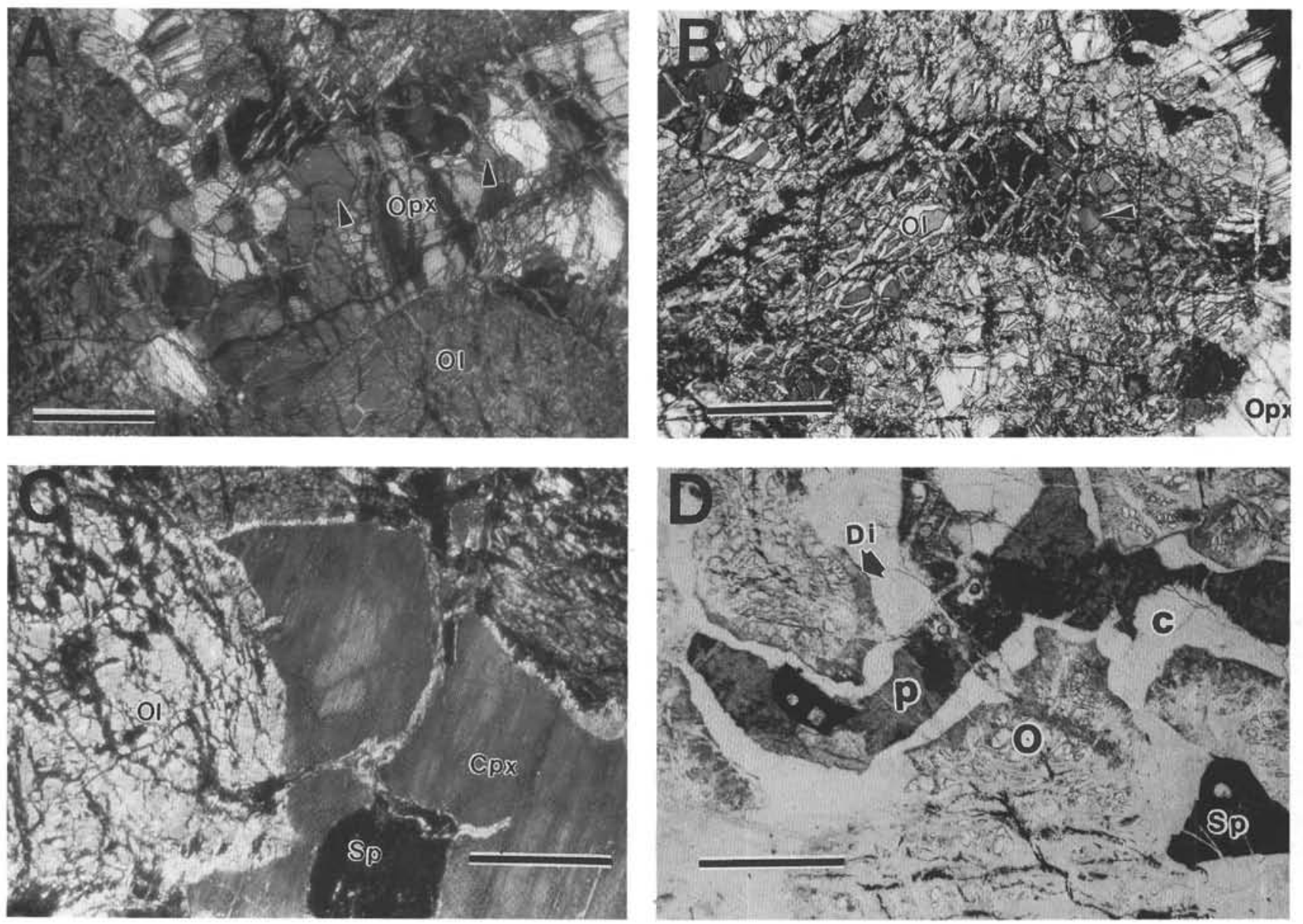

Figure 3. Deformation fabrics in harzburgites and plagioclase dunites. A. Harzburgite Sample 147-895C-1R-1 (Piece 9, 55-58 cm). Porphyroclastic texture with elongation of orthopyroxene (Opx) grains and mantling of olivine (Ol) by polygonal recrystallized Opx grains (see arrows). Scale bar is $1 \mathrm{~mm}$. B. Harzburgite Sample 147-895D-7R-2 (Piece 8,56-65 cm). Rounded olivine grains with a triple junction boundary, microstructures indicative of annealing and a high degree of recovery of the crystallographic lattice. Scale bar is $1 \mathrm{~mm}$. C. Troctolite Sample 147-895C-4R-2 (80-87 cm). Impregnations of clinopyroxene (cpx) in dunite; $\mathrm{cpx}$ is undeformed. Scale bar is $0.5 \mathrm{~mm}$. D. Plagioclase dunite Sample 147-895C-4R-2 (98-102 cm). Plagioclase (p) and spinel (Sp) impregnations. (c) represents chlorite. Diopside (di) is a common reaction product rimming olivine (o). Scale bar is $1 \mathrm{~mm}$.

teristic of high-temperature slip on the $\{\mathrm{Okl}\}<100>$ slip system (e.g., Avé Lallemant and Carter, 1970; Phakey et al., 1972; Green and Radcliffe, 1972; Kirby and Raleigh, 1973; Gueguen and Darot, 1982; Mackwell et al., 1990). At experimental strain rates, Phakey et al. (1972) found that slip on the $\{010\}<100>$ system occurs only at temperatures greater than $800^{\circ} \mathrm{C} ;\{010\}<100>$ slip is predominant at temperatures greater than $1000^{\circ} \mathrm{C}$. Dislocation densities determined from TEM plates are shown in Figure 7A and 7B. Average densities of olivine grains for troctolites are on the order of $3 \times 10^{6} \mathrm{~mm}^{-2}$. Given the very different resolutions and volumes of material observed by optical and TEM methods, the dislocation densities measured by TEM cannot be compared directly with those measured using optical micrographs. However, using dislocation densities measured on TEM plates, we estimate shear stresses associated with their accumulation of $\sim 128 \mathrm{MPa}$ for the troctolites.

\section{Mafic Rocks}

Several mafic rock types were recovered at Site 895 including olivine gabbros, troctolites and gabbros. In many cores, particularly in Hole $895 \mathrm{E}$, the gabbroic rocks are associated with dunites and may form sequences in which gabbros are bordered by olivine gabbros which in turn are bordered by troctolites, which may be bordered by dunite and finally by harzburgite. Although such associations are rarely complete, they are thought to represent a crystallization sequence with olivine + spinel crystallizing first followed by olivine + spinel + plagioclase, then, olivine + spinel + plagioclase + clinopyroxene, followed by plagioclase + clinopyroxene (Shipboard Scientific Party, 1993). Although most minerals comprising the mafic rocks appear to have crystallized from a melt, residual minerals are also present. For example, in some olivine gabbros, the olivine, at least in part, is residual in origin as suggested by multigranular aggregates of deformed and recrystallized olivine with well-developed (100) subgrain walls (a feature indicative of deformation under hightemperature, low-stress conditions).

Static metamorphism of the mafic rocks is recorded by greenschist mineral assemblages, including tremolite, chlorite and secondary clinopyroxene. Assuming that these assemblages reached equilibrium, the estimated temperatures of initial fluid infiltration range from $400^{\circ}$ to $500^{\circ} \mathrm{C}$ (Früh-Green, Plas, and Lécuyer, this volume). Olivine pseudomorphs are composed of tremolite and chlorite, and plagioclase is commonly replaced by chlorite, tremolite and secondary plagioclase. Continued infiltration of fluids appears to have occurred at progressively lower temperatures as indicated by the presence of prehnite, hydrogrossular, zeolites and clay minerals; the abundance of these minerals increases with increasing degrees of cataclastic deformation. Estimated temperatures for this low-temperature alteration range from $220^{\circ}$ to $420^{\circ} \mathrm{C}$ (Früh-Green, Plas, and 
$-108$
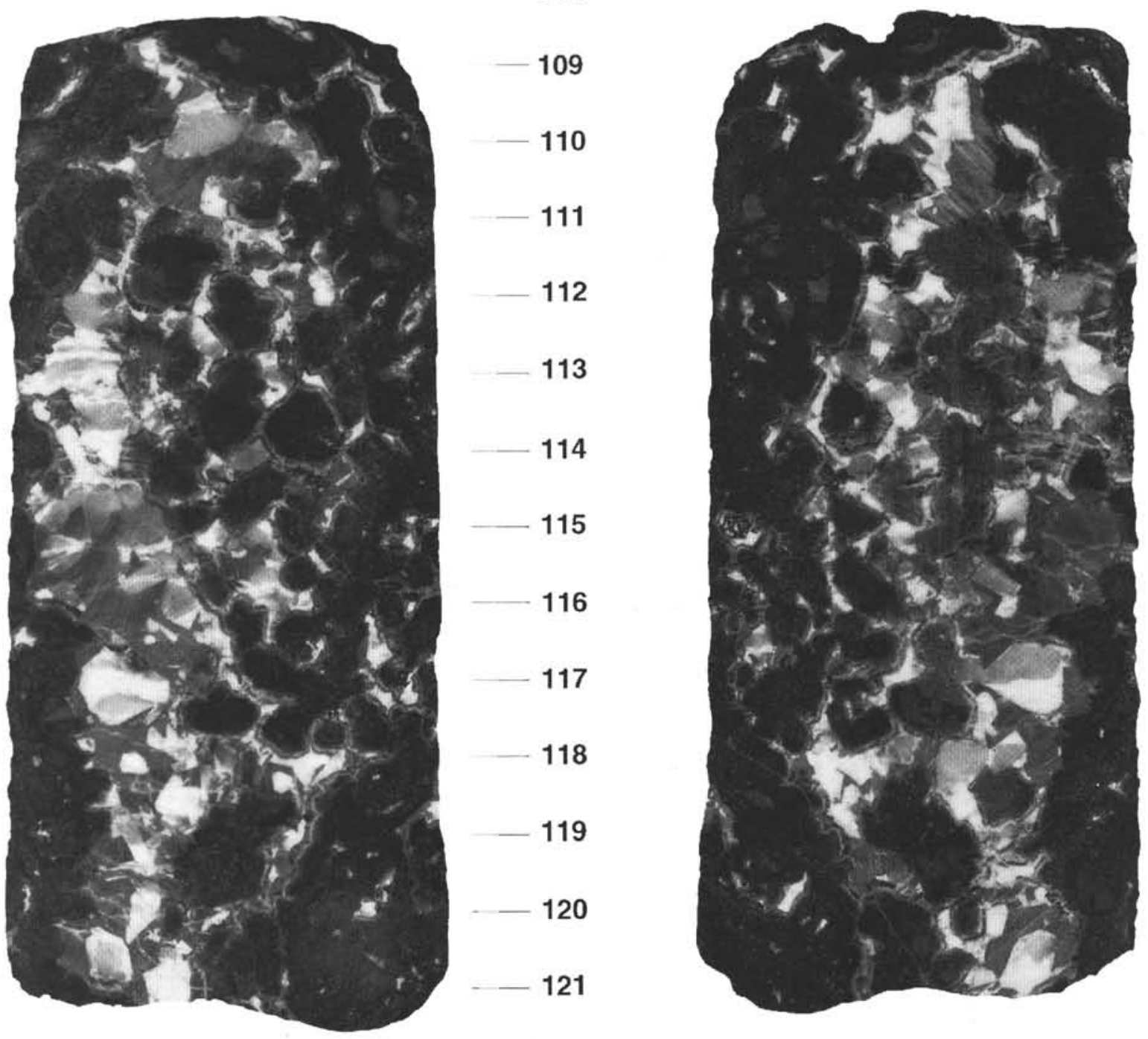

Figure 4. Plagioclase (white) and clinopyroxene (light gray) impregnations in dunite.

Lécuyer, this volume). The alteration products are heterogeneously distributed, the most altered samples coinciding with those regions that were most intensely deformed. Thus, central regions of shear zones are made up entirely of alteration products with mineralogy that reflects the new, lower-temperature conditions. Samples which display relatively homogeneous microcracking are less altered. Metamorphism occurred both during and after deformation.

The degree of deformation within the mafic cores is highly variable, although even the least deformed samples show undulatory extinction and microcracking of most phases. Locally the gabbroic rocks possess an early foliation, which may be magmatic in origin, and a second foliation directly related to brittle deformation. The latter most likely corresponds to rifting of the lithosphere by the CocosNazca propagator. This foliation is most pronounced directly below sheared contacts whereas the earlier "magmatic" foliation is developed sporadically throughout the cores. Also, the early formed foliation is commonly steeply dipping ( $>70^{\circ}$ relative to borehole axis), whereas the later-formed cataclastic foliation is commonly gently dipping ( $\sim 15^{\circ}$ relative to borehole). The foliation developed by ductile shearing processes varies widely and is well developed in some rocks, while it is absent in others. Where it is well developed, the earlier foliation is defined by alternating pseudomorphically replaced plagioclase and olivine grains (Figs. 8,9A). Olivine grains that are nearly completely replaced by radiating, undeformed tremolite are elongate and podiform in shape and occur as subparallel clusters. Because of the extensive degree of alteration, we cannot determine the origin of this foliation; it may have formed as a result of mechanical rotation, flattening, and corrosion of olivine during magmatic flow, or it may have formed by the injection of mafic minerals (plagioclase and clinopyroxene) along a series of en-echelon cracks.

The majority of brittle shear zones occurs at mafic rock/dunite contacts; high strains are localized and are restricted to less than 10 $\mathrm{mm}$ in width, although distributed cataclasis extends to greater distances from the contacts. Although oriented contacts between gabbroic rocks and peridotites were not recovered, four sheared contacts between dunite and olivine gabbro were recovered as unoriented peb- 

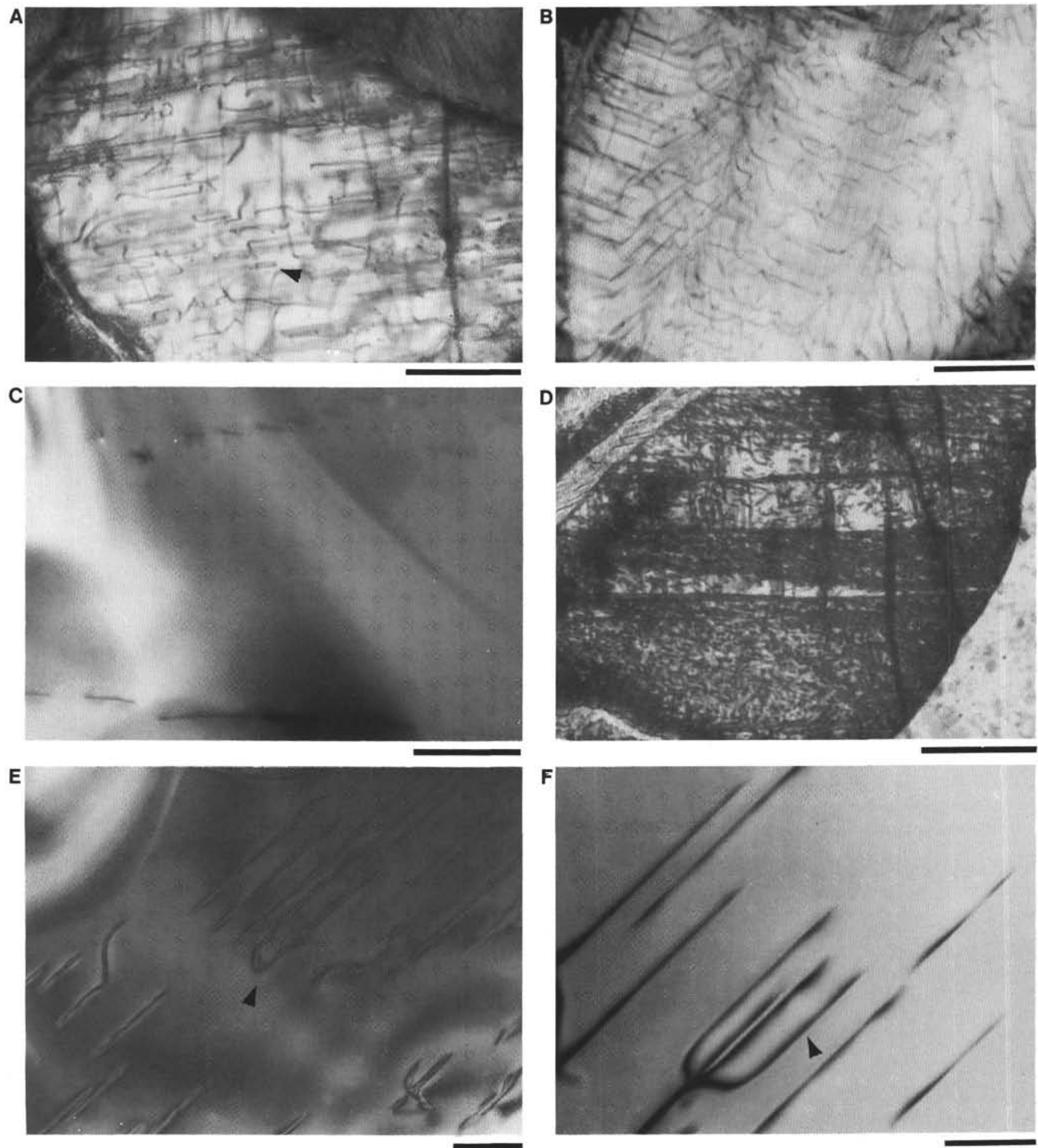

Figure 5. Optical and TEM photomicrographs of dislocation substructures of olivine grains from harzburgites and plagioclase dunites. A. Oxide-stained olivine grain from harzburgite. Sample 147-895E-7R-4 $(84-86 \mathrm{~cm})$. Dislocation substructures indicative of climb and recovery processes are present. Arrow points to a dislocation loop. Scale bar is $0.05 \mathrm{~mm}$. B. Oxide-stained olivine grain from harzburgite. Sample 147-895D-5R-2 (74-77 cm). This grain has multiple high-temperature glide loops. Scale bar is $25 \mu \mathrm{m}$. C. TEM image of olivine from harzburgite. Sample 147-895D-8R-2 (Piece 3, 25-28 cm). Free dislocations are rare in these grains. Tilt walls also are not abundant, but where present, are indicative of climb and recovery within the olivine grains. Scale bar is $100 \mathrm{~nm}$. D. Oxidestained olivine grain from troctolite. Sample 147-895C-4R-2 $(95-102 \mathrm{~cm})$. Olivine grains from troctolites have a significantly higher dislocation density than that recorded in olivine grains from harzburgites. Scale bar is $0.05 \mathrm{~mm}$. E. TEM image of olivine from plagioclase dunites. Long straight screw dislocations and short edge dislocations characterize this dislocation substructure and are indicative of deformation under high temperatures. Sample 147-895D-7R-1 (70-73 $\mathrm{cm}$ ). Scale bar is $400 \mathrm{~nm}$. F. TEM image of olivine from plagioclase dunites. Similar substructure to Figure 4. Sample 147-895D-7R-2 (Piece 8, 58-65 cm). In this sample, the prominent dislocations were identified as having a [100] Burgers vector (see arrow), indicating slip along the $\{\mathrm{OK} 1\}<100>$ slip system. This slip system is only activated at elevated temperatures. Scale bar is $200 \mathrm{~nm}$. 
$A_{1}$

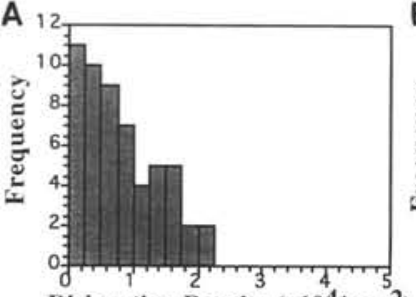

Dislocation Density $\left(\times 10^{4} / \mathrm{mm}^{2}\right)$
$B_{1}$

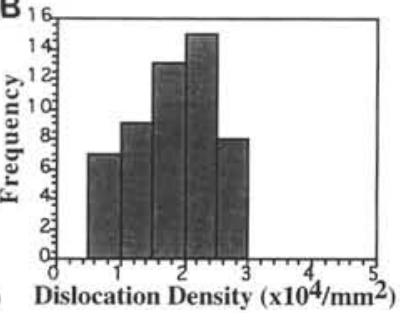

Figure 6. A. Optical dislocation density measured in olivine grains within harzburgite. Measurements made from Holes $895 \mathrm{C}$, D, and E. Database consisted of 10 oxidized thin sections. B. Optical dislocation densities measured in olivine grains within troctolites. Measurements made from Holes 895C, D, and E. Database consisted of 10 oxidized thin sections.

A

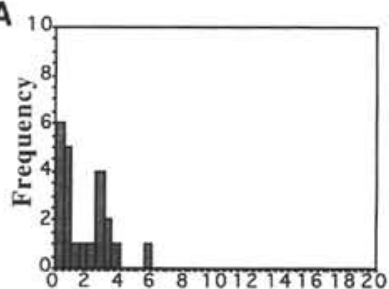

Dislocation Densities (x106/mm²)

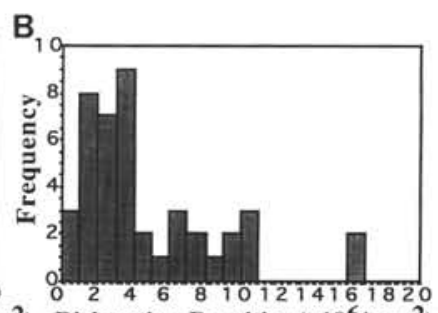

Dislocation Densities $\left(x 106 / \mathrm{mm}^{2}\right)$

Figure 7. A. TEM dislocation densities measured in olivine grains from within harzburgite. Measurements made from four sections taken from Holes 895D and E. B. TEM dislocation densities measured in olivine grains from within troctolites. Measurements made from four sections taken from Holes $895 \mathrm{C}$ and $\mathrm{E}$.

bles (Samples 147-895D-8R-2, Piece 19, 145-151 cm; 147-895E1R-1, Piece 1, 1-4 cm; 147-895E-4R-2, Piece 17, 138-140 cm; 147 895E-6R-1, Piece 14, 74-77 cm). Evidence for multiple episodes of melt impregnation at Hole $895 \mathrm{E}$ includes crosscutting relationships, with gabbros that appear to have been injected into "host" rock olivine gabbros (e.g., Samples 147-895E-4R-3, 0-10 cm; 147-895E-1R$1,133-143 \mathrm{~cm}$ and an unoriented dike contact (Sample.147-895D$8 \mathrm{R}-1$, Piece $10,65-73 \mathrm{~cm}$ ) that consists of a 40 -mm-wide olivine gabbro dike in contact with a foliated plagioclase dunite; one side of this olivine gabbro has a finer grained margin (Fig. 10).

The majority of brittle shear zones are located at contacts between olivine gabbros and dunite, rather than at contacts between gabbro and dunite. The sheared contacts between olivine gabbro and dunite commonly display a shear zone fabric which is commonly developed in brittle shear zones, termed a Riedel shear fabric (Fig. 9B; Logan et al., 1979), while contacts between gabbro and dunite do not show Riedel shear surfaces. Brittle shear zones from Site 895 do not possess all of the shear and fracture surfaces and foliations characteristic of a Riedel shear fabric. However, $R_{1}$ shear surfaces at a low angle $\left(<30^{\circ}\right)$ to the shear zone boundaries are present. Also, a "P" foliation defined by chlorite is oriented at a low angle to the sheared contact. Slip surfaces oriented parallel to the contacts are present and define the Riedel "Y" plane. Relict igneous plagioclase grains in these samples display undulatory extinction and cataclasis. These plagioclase clasts are sigmoidal in shape and thus serve as kinematic indicators (Fig. 9C); in all cases, a normal sense of shear within the core was observed. With distance from the sheared olivine gabbro/dunite contacts, brittle deformation intensity decreases; foliated cataclasites grade into rocks with more distributed microcracking with only very localized, discrete slip surfaces.

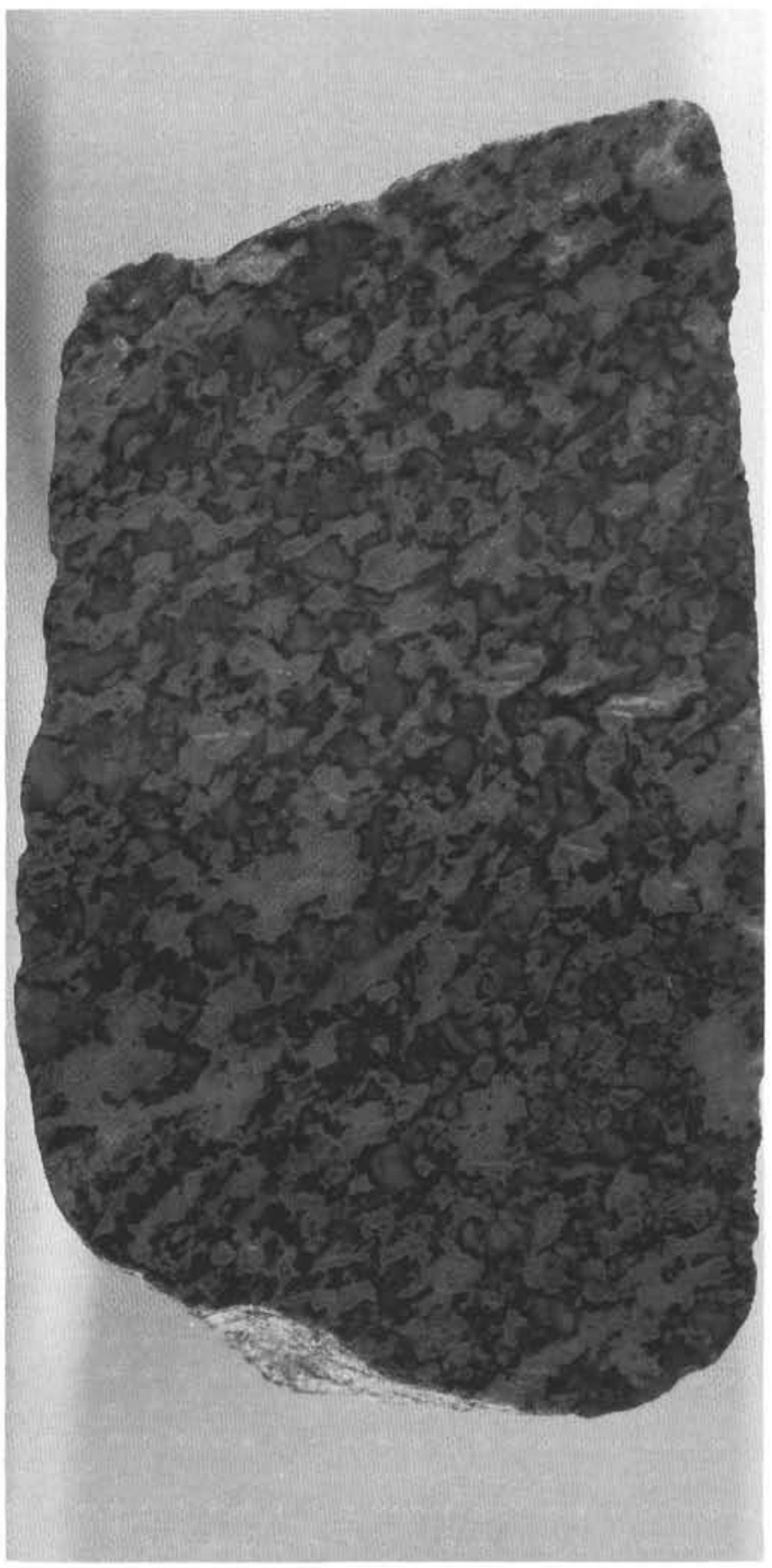

Figure 8. Photograph of a foliated gabbro. The foliation is defined by alternating elongate plagioclase and tremolite/chlorite clusters. Neither the plagioclase nor the tremolite/chlorite clusters are deformed, indicating that the fabric formed before metamorphism (Sample 147-895E-1R-3, Piece 9, 113$124 \mathrm{~cm})$.

The gabbros commonly have abundant, large $(10-20 \mathrm{~mm})$ diopsidic clinopyroxene grains which possess a closely spaced (100) cleavage. The clinopyroxene grains may have exceptionally well-developed conjugate kink bands (Fig. 9D), and the (100) spaced cleavage cracks may be folded (Fig. 9E). These grains display strong undulatory extinction and are commonly elongated due to displacement along the (100) cleavage planes. Discontinuous prehnite veins cross- 

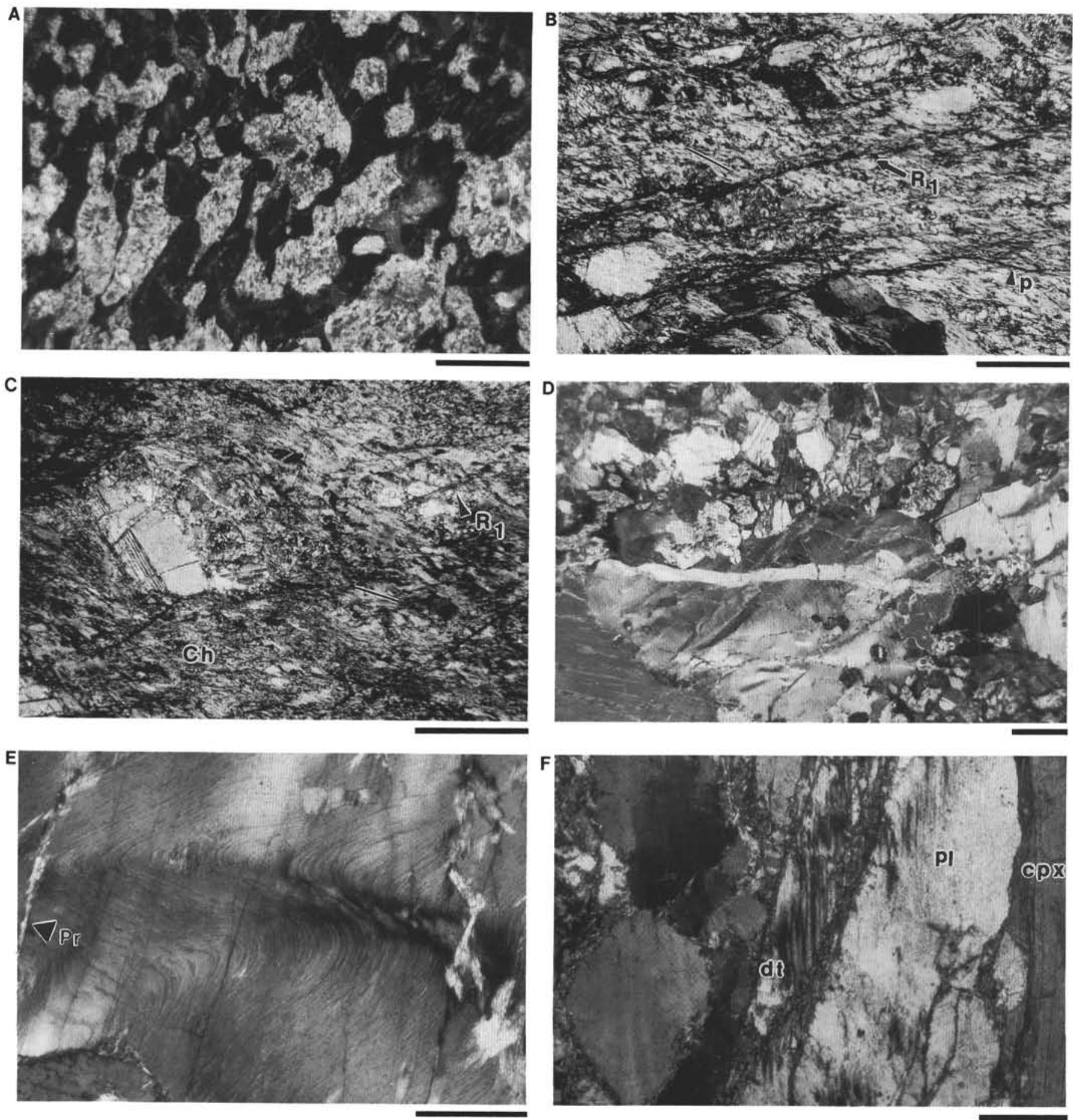

Figure 9. Photomicrographs of deformation microstructures in gabbroic rocks. A. Well-foliated olivine gabbro. Foliation is defined by alternating pseudomorphically replaced plagioclase and olivine grains and, hence, predates metamorphism. This foliation was not formed by brittle shearing and may represent a magmatic process. Sample 147-895E-1R-3 (Piece 9, 113-124 cm). Scale bar is $1 \mathrm{~mm}$. B. Sheared olivine gabbro. Sample 147-895E-1R-1 (Piece 3A, 11-13 cm). A Riedel shear fabric is developed, showing $\mathrm{R}_{1}$ and $\mathrm{p}$ surfaces. Shape fabric (line) is defined by aligned chlorite. Sample was taken from about $10 \mathrm{~cm}$ below a sheared olivine gabbro/dunite contact. Sense of shear, top to the left. Scale bar is $1 \mathrm{~mm}$. C. Microfaulted and altered plagioclase grain in olivine gabbro indicating a top to the left sense of shear. Sample 147-895E-1R-1 (Piece 3A, 11-13 cm). Ch represents chlorite. Scale bar is $0.5 \mathrm{~mm}$. D. Kink bands in diopsidic clinopyroxene grain. Sample 147-895E-4R-3 (39-44 cm). Scale bar is $1 \mathrm{~mm}$. E. Microfolded (100) lamellae in diopsidic clinopyroxene. Pr indicates a crosscutting prehnite vein. Sample 147-895E-4R-3 $(39-44 \mathrm{~cm})$. Scale bar is $0.5 \mathrm{~mm}$. F. Elongated plagioclase with deformation twins (dt). Plagioclase (pl) grains also have undulose extinction and are commonly extensively fractured. Cpx represents clinopyroxene. Sample 147-895E-4R-3 (39-41 cm). Scale bar is $0.1 \mathrm{~mm}$. 
cut most deformation features but are also folded and kinked, indicating that the low-temperature alteration occurred both during and after brittle deformation. Clinopyroxene is partially altered to tremolite, which helps to define the foliation. Tremolite is commonly deformed, which indicates that tremolite grew before the final low-temperature, brittle deformation.

Plagioclase in the gabbroic rocks display features characteristic of cataclastic flow (e.g., Tullis and Yund, 1987) with intracrystalline fracturing, microfaulting, grain elongation and undulatory extinction. Twins are also present with geometries and relationships that suggest that they were introduced by deformation (Fig. 9F). Albite lamellae are offset and altered along the cleavage plane. Plagioclase grains are also fractured, extended perpendicular to cleavage and infilled with fibrous chlorite. Plagioclase is variably altered to hydrogrossular and other minerals (Früh-Green, Plas, and Lécuyer, this volume); this alteration occurred during and after the low temperature deformation. In most foliated samples, plagioclase contributes to the foliation by (1) grain elongation due to fracturing and cataclasis and (2) alignment of podiform aggregates of anhedral and subhedral grains of plagioclase.

Dislocation geometries and densities were discussed earlier for the troctolites. In olivine from iron-oxide stained olivine gabbros dislocations are heterogeneously distributed; many grains are nearly devoid of dislocations, reminiscent of olivine grains from harzburgite, while other grains have dislocation densities resembling that observed in the troctolites. Similar to olivine grains from harzburgite, (100) tilt boundaries which result from activation of the $\{0 \mathrm{kl}\}\langle 100\rangle$ slip system are apparent, but generally, are not well formed. Dislocation loops with geometries that reflect glide from a common source are present as are free dislocations. Many grains also have dislocation substructures similar to those observed in troctolites, consisting primarily of dense, aligned, straight dislocations.

\section{Sheared Contacts}

Of the four recovered (though unoriented) sheared contacts, two occur at the top of gabbroic sections (147-895E-1R-1 and 147-895E$4 \mathrm{R}-2$ ), with $1.4 \mathrm{~m}$ and $0.5 \mathrm{~m}$ of gabbro below the contact, respectively. Other sheared contacts occur amongst mixtures of dunite/ harzburgites and gabbro. Typically, the dunite within shear zones is completely replaced by chlorite and tremolite. Localized slip surfaces are defined by thin folia of oxides, tremolite and chlorite. Away from these surfaces, the tremolite and chlorite are less deformed, although there is a foliation defined by the elongation of pseudomorphic olivine grain shapes. Discrete slip surfaces occur in the dunite and foliations occur locally in tremolite. The gabbroic portions of the sheared contact consists of highly fractured and altered clasts of plagioclase in a secondary chlorite matrix. Again, close to the sheared zone, the chlorite is deformed, while at a distance, it appears undeformed, suggesting that alteration to tremolite and chlorite occurred before a latestage deformation.

\section{Intrusive Contacts}

One unoriented specimen recovered in Hole 895D exhibits an olivine gabbro dike in contact with a troctolitic host rock (Sample 147895D-8R-1, 65-73 cm; Fig. 10). The troctolites has a shape fabric defined by the lenticular shape of both olivine and plagioclase crystals. Olivine grains in the troctolites have triple junctions with embayed grain boundaries and rare (100) subgrains and microstructures characteristic of high-temperature conditions (e.g., Nicolas, 1990). In contrast to textures in the troctolites, most olivine grains in the dike do not have triple junctions at textural equilibrium, nor do they possess (100) subgrains, indicating that they crystallized from a melt after the high-temperature deformation event. However, a few olivine grains with deformation textures similar to that observed in dunite also occur in the dike and have been interpreted as dunite xenoliths.

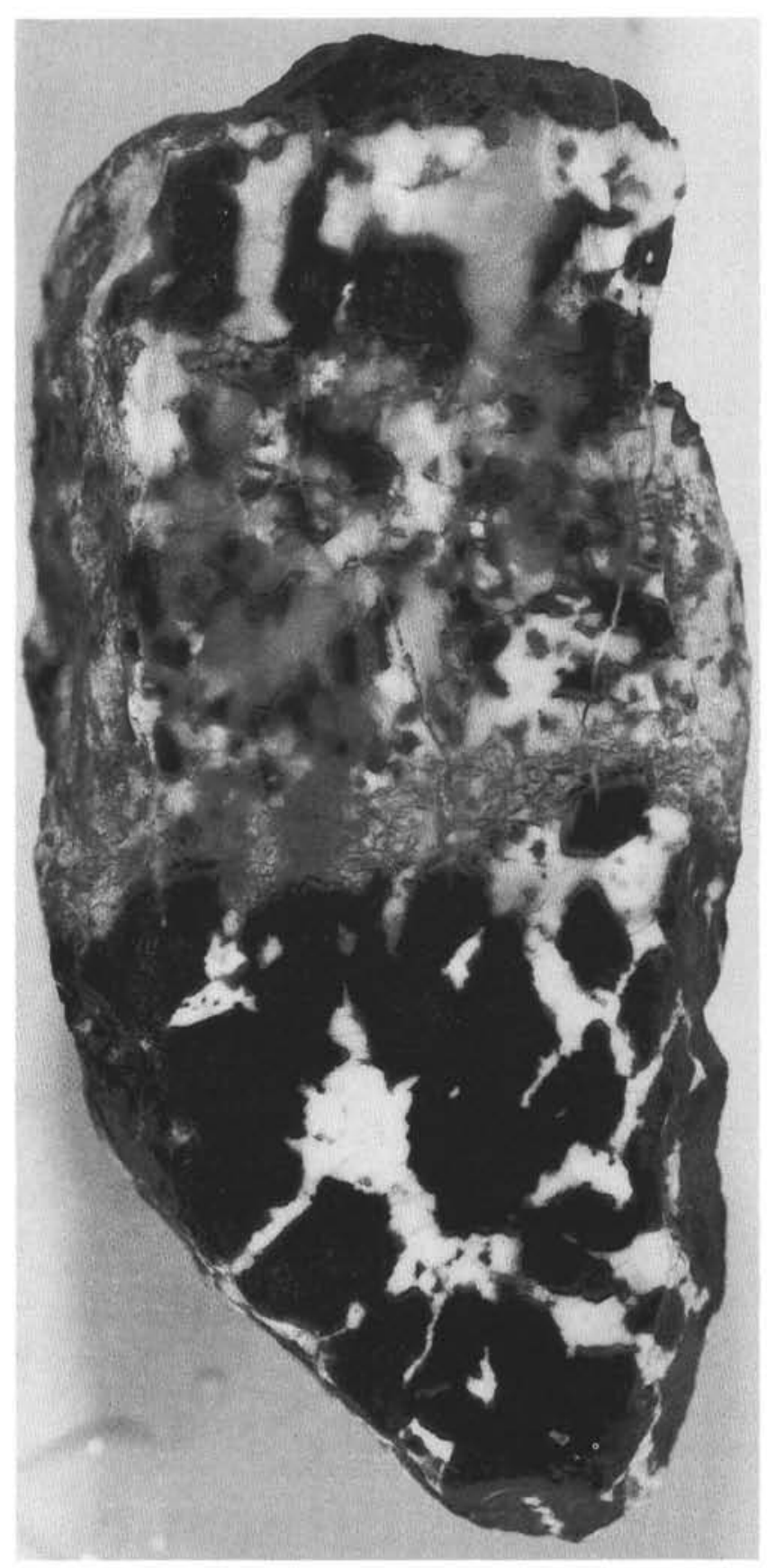

Figure 10. Contact between plagioclase dunite and olivine gabbro, indicating at least two episodes of melt injection. Note the finer grained margin to one side of the olivine gabbro. The troctolite is weakly foliated; the gabbro has no foliation.

\section{Summary}

Both harzburgites and dunites display fabrics that suggest that these upper-mantle rocks were deformed at the high temperatures of the asthenosphere. The majority of dunites are interpreted as residual in origin, derived from the dissolution of pyroxene during interaction with a migrating mafic melt. Only few of the dunites could have been formed as cumulates at the base of a melt body. The dunites contain variable amounts of mafic minerals, located along grain boundaries and triple junctions. For samples with large proportions of plagio- 
clase, clinopyroxene and spinel, small mafic veins and dikes (millimeters in size) are observed. These mafic minerals are not deformed and thus post-date the high temperature deformation experienced by the peridotites. Dislocation densities in olivine grains of troctolites are higher than those of olivine within harzburgites and dunites; thus the introduction of dislocations in the troctolites appears to correspond to a late-stage locally higher stress deformation that did not affect the harzburgites. Dislocation geometries and identification of the [100] Burgers vector for dislocations in olivine grains from the troctolites suggest that the introduction of dislocations occurred at relatively high temperatures; dislocations with the [100] Burgers vector are not activated in experiments performed on olivine at temperatures below $800^{\circ} \mathrm{C}$.

The olivine gabbros locally have two foliations. We interpret one foliation as representing a magmatic foliation. In many instances, the olivine and plagioclase which define this foliation are heavily altered and are replaced by tremolite and chlorite. A later cataclastic foliation is most intense near sheared dunite/olivine gabbro contacts and, in most cases, diminishes in intensity with distance from the contact. The cataclastic deformation observed in gabbroic rocks is absent from harzburgites, dunites, and troctolites, except at sheared contacts.

\section{DISCUSSION}

The drill core recovered from Site 895 records three deformational events: (1) harzburgite and dunite have deformational features indicative of a high-temperature, low-stress deformation, including, a porphyroclastic texture, a foliation defined by elongated spinel and orthopyroxene grains and curved olivine grain boundaries which meet at triple junctions. These microstructures are similar to those observed in the mantle sections of ophiolites (e.g., Nicolas, 1989) and hence, their deformation has been interpreted to have occurred at the high temperature conditions of the asthenosphere (Boudier et al., this volume); (2) dunites, which have patches and veins of undeformed plagioclase, clinopyroxene, and spinel, have been subjected to a later, locally high-stress deformation while harzburgites lacking interstitial mafic minerals escaped this deformation, and (3) the gabbroic rocks from Site 895 have two foliations, an earlier formed foliation which may be magmatic in origin and a foliation related to brittle shearing that likely corresponds to the rifting of the lithosphere by the CocosNazca propagator. Cataclastic deformation of the Hess Deep peridotites is highly localized within the mantle gabbros. With the exception of sheared dunite contacts, the harzburgites, dunites, and troctolites are practically devoid of cataclastic deformation. This apparent strain localization within the gabbroic rocks indicates that the gabbros were weaker than the surrounding peridotite at the time of brittle deformation. The gabbros may have become relatively weak as a result of a larger number of cracks and pores (as rock strength decreases with increasing porosity). Alternatively, alteration products of the gabbros, including tremolite and chlorite, may have weakened these rocks relative to the surrounding ultramafic units.

Textural relationships in the Site 895 gabbros indicate that an early foliation developed before the first metamorphic episode; tremolite and chlorite that replace plagioclase and olivine are not deformed. Studies of metamorphic products (Früh-Green, Plas, and Lécuyer, this volume) demonstrate that initial metamorphism resulted in a tremolite + diopside + chlorite assemblage, which indicates temperatures in excess of $430^{\circ} \mathrm{C}$. There are two possibilities for the formation of this podiform foliation: (1) magmatic flow accompanying deformation of a melt-rock aggregate, or (2) injection of mafic melt into an en-echelon crack geometry located at the tip of a propagating dike.

\section{Melt Emplacement}

The close and consistent associations of harzburgite, dunite, and gabbroic units in the drill core from Site 895 suggest that melts have been localized and transported in conduits of unknown shape through this section of the shallow mantle of the East Pacific Rise. Based on petrological and microtextural observations, the rocks in this area are interpreted to result from complex interactions between melt and the crystalline solids, with partial melting, multiple episodes of melt injection, wall-rock reactions and cumulus olivine precipitation (Dick and Natland, this volume; Allan and Dick, this volume). Most of the dunites are interpreted to represent a residual crystal fraction following melt extraction while only few dunites could represent cumulates associated with olivine precipitation from a melt. We suggest that the troctolites represent regions in which melt infiltrated and disaggregated dunites, with the melt crystallizing to clinopyroxene, plagioclase, and spinel within interstices. The distributions of clinopyroxene, plagioclase, and spinel pockets record the textures and geometries of melt pathways during melt transport and impregnation. This trapped melt is not deformed and thus post-dates the high-temperature, low-stress deformation to which the harzburgites were exposed. The presence of an olivine gabbro dike which crosscuts a foliated, melt-impregnated dunite and the presence of crosscutting olivine gabbros suggests that the Hess Deep peridotites were subjected to several episodes of melt injection. From these observations, we suggest that the dunites and early formed gabbroic segregations may represent melt pathways which continued to serve as conduits for melt transport during several episodes of melt introduction. The possible mechanisms of melt transport through these rocks are discussed below.

Dislocation densities in olivine grains of the peridotites and the melt-impregnated dunites and gabbros differ and suggest differences in their late-stage deformation that may place constraints on the mechanisms of melt emplacement. The marked increase in dislocation density in olivine grains of troctolites compared to that recorded in the harzburgites and dunites is evidence for locally high stresses in both the melt-impregnated dunites and the gabbros during late stages of high-temperature deformation which were not experienced by the dunites and harzburgites. If we assume that the introduction of melt is responsible for the local increase in stress, then our data suggest processes of melt transport that were rapid, in contrast to stresses expected for the slow percolation of melt and compaction of surrounding solid matrix. This inference is consistent with the results of geochemical studies; analyses of the distributions of elements in the mafic rocks and the mafic components in the melt-impregnated dunites indicate that they are not in chemical equilibrium with the Hess Deep mantle rocks (Dick and Natland, this volume). This observation requires that melt transport was sufficiently rapid through the residual mantle peridotites to prevent equilibrium of the mafic melt with the surrounding peridotites.

There are four possible ways to generate heterogeneous, locally high stresses within olivine grains from troctolites under the conditions prevalent at the Hess Deep: (1) later rifting of this mantle section by the Cocos-Nazca propagator; (2) cooling and thermal expansion anisotropy and thermal strain mismatches between neighboring grains; (3) the intrusion of melt via cracks or dikes; and (4) the rapid flow of melt in dissolution channels.

We examine these models in light of our observations of the deformation microstructures and dislocation densities. Rifting of the EPR lithosphere by the Cocos-Nazca propagator could readily impose high stresses on the peridotites. However, this would require that the stresses were localized within the melt-impregnated rocks as olivine grains from harzburgites and dunites do not record a later, high-stress deformation. Moreover, identification of the [100] Burger's vector in olivine within the melt-impregnated dunites indicates that the straight, dense dislocations observed by optical microscopy were generated at high temperatures; experiments on olivine have shown that the $\{0 \mathrm{kl}\}<100\rangle$ slip system in olivine is activated at $>800^{\circ} \mathrm{C}$, and is the predominant slip system only at temperatures in excess of $1000^{\circ} \mathrm{C}$ (Phakey et al., 1972). Brittle shearing of the Hess Deep mantle gabbroic rocks occurred under progressively decreasing 
temperatures, as indicated by an abundance of prehnite + hydrogrossular \pm a zeolite phase. Isotope data and thermodynamic considerations indicate that the last phase of fluid infiltration probably occurred at about $250^{\circ}-300^{\circ}$ (Früh-Green, Plas, and Lécuyer, this volume). An increase in the amount of prehnite and hydrogrossular in the gabbros is directly correlated with an increase in the degree of cataclasis; cataclastic shear zones are commonly the most highly altered sections of the gabbros, suggesting that they acted as conduits for fluid flow during deformation associated with rifting of the EPR mantle by the Cocos-Nazca propagator. These observations indicate that rifting of the Hess Deep did not introduce the high-temperature dislocations of olivine grains of the troctolites; rather, rifting was responsible for late-stage shearing and cataclastic textures.

Alternatively, stress concentrations in olivine grains may have been generated during cooling. We estimated stresses generated during cooling associated with thermal expansion mismatches between neighboring grains. Maximum stresses generated between neighboring olivine grains occur if their respective $a$ and $b$ axes are parallel and that these crystallographic axes are orthogonal to their grain boundary. Assuming that strains are equal in both crystals due to bonding across their grain boundary, thermally induced differential stresses $\sigma$ may reach values given by:

$$
\sigma=\frac{E_{a}\left(\alpha_{a}-\alpha_{b}\right) \Delta T(1)}{\left(1+E_{a} / E_{b}\right)}
$$

where $\mathrm{E}_{\mathrm{a}}$ and $\mathrm{E}_{\mathrm{b}}$ are the effective Young's moduli in the $a$ and $b$ directions, $\alpha_{a}$ and $\alpha_{b}$ are the corresponding coefficients of linear thermal expansion, and $\Delta \mathrm{T}$ is the temperature range over which the crystals cool. Using data from Suzuki et al. (1983), we use $E_{a}=2.65 \times$ $10^{2} \mathrm{GPa}$ and $\mathrm{E}_{\mathrm{b}}=1.48 \times 10^{2} \mathrm{GPa}$. Based on geochemistry, wall rock temperatures during melt impregnation were $\sim 1100^{\circ} \mathrm{C}$ or greater (Allan and Dick, this volume) and the difference between the thermal expansion coefficients $\alpha_{a}-\alpha_{b}$ varies from $6.4 \times 10^{-6 \circ} \mathrm{C}^{-1}$ to $7.1 \times$ $10^{-6 \circ} \mathrm{C}^{-1}$ between temperatures of $1200^{\circ}$ to $1000^{\circ} \mathrm{C}$, respectively. Activation of the $\{\mathrm{OkI}\}<100\rangle$ slip system is not expected at $<800^{\circ} \mathrm{C}$; hence the maximum temperature drop we consider for olivine grains during thermal cooling is $300^{\circ} \mathrm{C}$ yielding maximum differential stresses generated by cooling of $300 \mathrm{MPa}$ or shear stresses of $150 \mathrm{MPa}$. While this stress estimate is more than sufficient to account for the high dislocation densities in olivine of the troctolites, low dislocation densities are observed in olivine grains of harzburgites, which presumably experienced similar cooling histories. The majority of dislocations generated in the olivine crystals during initial crystallization and cooling may have been eliminated by recovery processes prior to the emplacement of mafic melt. Alternatively, small displacements at grain boundaries due to grain boundary sliding may have relaxed stresses between grains and the thermal strains may have readily been accommodated without introducing large dislocation densities. All of the above factors contribute to reductions in differential stresses generated in olivine grains by thermal cooling, and we conclude that increased dislocation densities in olivine of the troctolites are not primarily the result of cooling.

The intrusion of melt by a propagating visco-elastic crack could also generate local shear stresses that result in deformation of olivine grains. Rubin (1993) modeled the propagation of basaltic dikes within a visco-elastic host and examined those conditions for which the host rock was essentially elastic-brittle and those conditions required for time-dependent visco-elastic response. Based upon mantle viscosities for the host rock $\left(10^{17}\right.$ to $\left.10^{21} \mathrm{~Pa} . \mathrm{s}\right)$ and viscosities for basalts ranging from $10^{0}$ to $10^{2} \mathrm{~Pa} . \mathrm{s}$, Rubin (1993) concluded that the mantle will behave essentially elastic-brittle during intrusion of basaltic dikes. We calculated effective viscosities of olivine aggregates using experimentally determined flow laws (Mackwell et al., 1990), of the form:

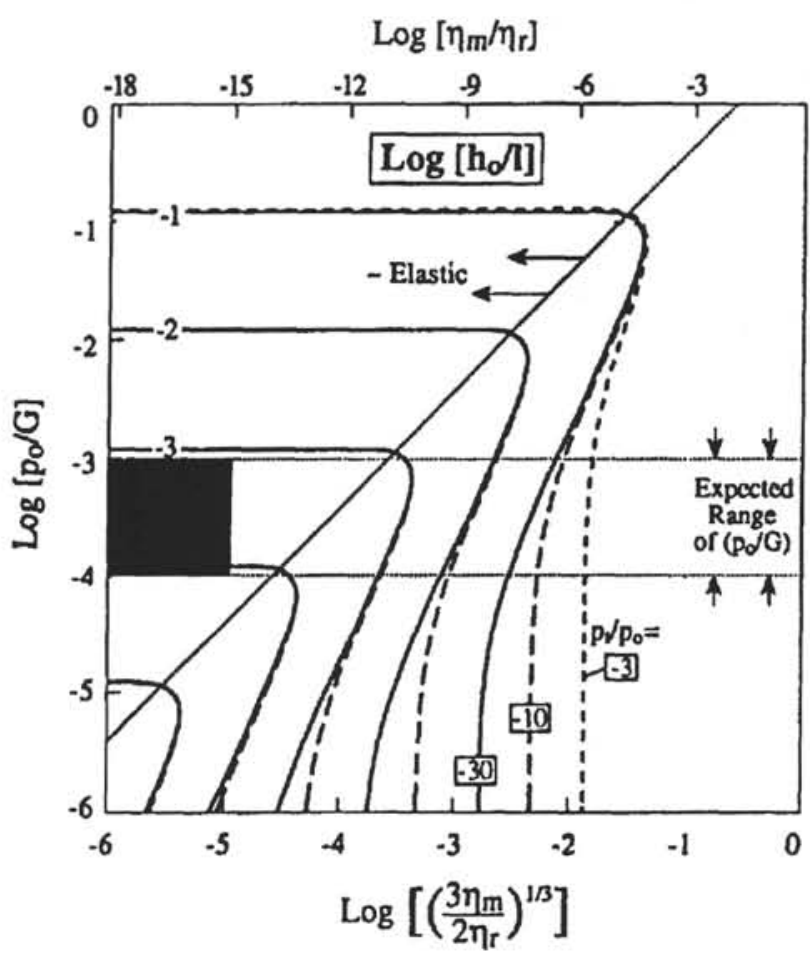

Figure 11. Log plot for predicting an elastic vs. visco-elastic response of host rock under various viscosities for host rock and melt. Contours represent log dike aspect ratio $h_{o} / l$ for $p_{1} / p_{o}=-30$ (solid curve), -10 (long dashes), and -3 (short dashes), where $h_{0}$ is the thickness at the dike center, $l$ is the dike length, and $\mathrm{p}_{u} \mathrm{p}_{\mathrm{o}}$ is the dike tip pressure. $\rho_{\mathrm{o}}$ is magma pressure at entrance to dike and $G$ is host rock elastic stiffness. $\eta_{m}$ is the viscosity of the melt, and $\eta_{r}$ is the viscosity of the host rock. Diagonal line separates elastic from viscoelastic region. Black box indicates area in which our data plots for possible dike impregnation at the Hess Deep. Diagram taken from Rubin (1993).

$$
\dot{\varepsilon}=A \sigma^{\mathrm{n}} \mathrm{f}_{\mathrm{O}_{2}}{ }^{\mathrm{m}} \mathrm{a}_{\text {opx }}{ }^{\mathrm{q}} \exp (\Delta \mathrm{H} / \mathrm{RT})
$$

where $\dot{\varepsilon}$ is the creep rate, $\mathrm{A}$ is an empirical constant, $\mathrm{n}$ is the stress exponent, $\mathrm{m}$ is the oxygen fugacity exponent, $\mathrm{q}$ is the orthopyroxene activity exponent, $\Delta H$ is the activation enthalpy, and $R$ is the gas constant. Effective viscosities for olivine aggregates under all mantle conditions fall within the range considered by Rubin (1993) for the host rock, and suggest that dikes will propagate in an elastic-brittle manner throughout the mantle (Fig. 11). However, if the presence of melt substantially lowers viscosities of olivine-melt aggregates (e.g., Parmentier and Schubert, 1989), dikes may propagate in a visco-elastic fashion and explain the dislocations introduced in olivine grains.

The final mechanism which may be responsible for the increased dislocation densities observed in the melt-impregnated dunites involves melt transport through solution channels as proposed by Kelemen et al. (1995). In this model, solution channels form a branching, arterial geometry and in this way melt is transported through the mantle at a faster rate possible than by uniform porous flow. Heterogeneities in solid porosities are expected to result in heterogeneities in differential stresses and local compaction rates. Upper bounds on these local stress concentrations are given by elastic solutions for stresses in the vicinity of a hole, reaching three times the far-field uniform stress (e.g., Timoshenka and Goodier, 1934). Depending upon the conditions of deformation and rates of compaction, local stresses sur- 


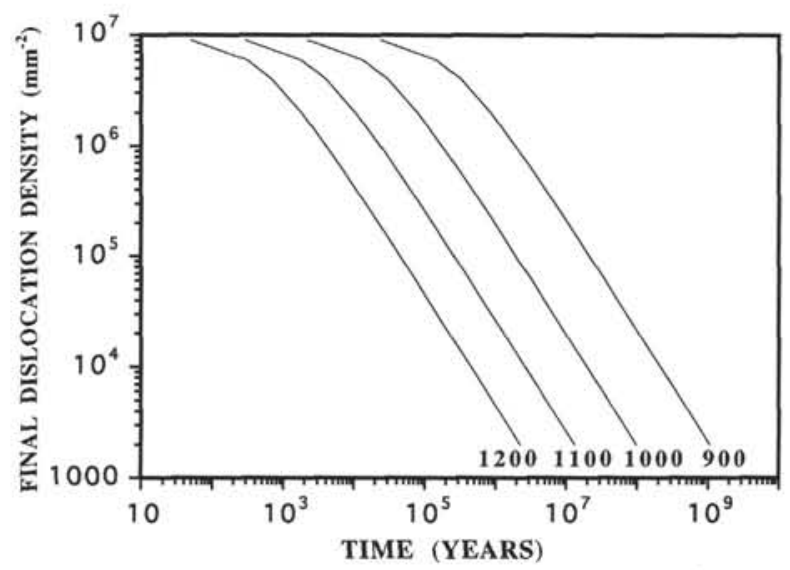

Figure 12. Plot illustrating the time required for dislocation densities to anneal over a variety of wall-rock temperatures $\left({ }^{\circ} \mathrm{C}\right)$. The $\mathrm{Y}$ axis plots initial dislocation density (we assume $10^{7} \mathrm{~mm}^{2}$ ) minus final density (variable). Equation to determine the time required to anneal dislocation is from Kohlstedt et al. (1980).

rounding conduits may be significantly smaller than the elastic estimate. However, shear stresses associated with the increased dislocation densities of olivine grains from melt-impregnated dunites $(\sim 165$ $\mathrm{MPa})$ in excess of those experienced by harzburgites ( $65 \mathrm{MPa})$ may be explained by the increased stresses and compaction rates associated with solution channels.

Regardless of which mechanism was responsible for generation of dislocations in olivine grains from troctolites, rapid cooling relative to recovery rates must be invoked following melt impregnation in order to explain the persistence of locally high dislocation densities. We calculated the times required for an initial dislocation density of $10^{7} \mathrm{~mm}^{-2}$ to anneal to various degrees, under a variety of temperatures using experimentally determined rates of dislocation annihilation (Kohlstedt et al., 1980); dislocation densities $\sigma$ are reduced with time, following the relationship:

$$
(\rho \circ / \rho)-1=K_{3} t \exp [-(Q+P V) / k T]
$$

where $\mathrm{t}$ is the annealing time, $\rho 0$ is the initial dislocation density, $\mathrm{k}$ is Boltzmann's constant, $Q$ is the activation energy for creep and $K_{3}$ is a constant. Based on these calculations (Fig. 12) high dislocation densities in olivine grains may be preserved under some, but not all, conditions found in the mantle. For wall-rock temperatures of $1200^{\circ} \mathrm{C}$, dislocation densities greater than $2 \times 10^{6} \mathrm{~mm}^{-2}$ or $2 \times 10^{5}$ $\mathrm{mm}^{-2}$ will be preserved for (metamorphic) annealing times of $\sim 2000$ years or $\sim 20,000$ years, respectively. At wall rock temperatures of $1100^{\circ} \mathrm{C}$, the same dislocation densities will be preserved for (metamorphic) annealing time spans of $\sim 10,000$ or $\sim 100,000$ years, respectively.

\section{CONCLUSIONS}

The close association of harzburgite, dunite, troctolites, olivine gabbro, and gabbro in the core recovered from the mantle exposed at Hess Deep suggests that these rocks belong to a suite of tectonized residual mantle peridotites through which a mafic melt was transported. Their textures observed at macroscopic and microscopic scales are interpreted in terms of igneous and metamorphic processes, including partial melting, multiple episodes of melt injection, wall-rock interactions and cumulus olivine precipitation (Dick and Natland, this volume; Allan and Dick, this volume). Optical and TEM micro- structures indicate that processes of rapid, episodic melt migration were important.

Optical dislocation substructures in olivine from harzburgites, such as the presence of (100) tilt boundaries, dislocation helices, and dislocation loops, indicate that dislocation recovery proceeded at conditions of the asthenosphere. Based on olivine dislocation densities from harzburgites, these rocks experienced shear stresses as large as $\sim 65 \mathrm{MPa}$.

The undeformed nature of interstitial plagioclase, pyroxene and spinel that appear to have been introduced into previously deformed dunite indicates that the crystallization of these phases from a mafic melt post-dates the high-temperature deformation of olivine associated with asthenospheric flow. Dislocation densities of olivine grains in the melt-impregnated dunites are higher than those of olivine within the harzburgites and dunites. Dislocation densities, dislocation geometries and identification of the high temperature [100] Burgers vector in olivine grains of the troctolites suggest that these dislocations were introduced during a late, locally high-stress ( 130 MPa) and high-temperature $\left(>800^{\circ} \mathrm{C}\right)$ deformation. Two rapid mechanisms of melt impregnation may have been responsible for this late-stage deformation: (1) melt may have been introduced by the rapid propagation of dikes in which the wall rock deforms in a visco-elastic manner, given that interstitial melts reduced the effective viscosity of the wall rocks below that of melt-free dunite; and (2) the rapid melt introduction within dissolution channels associated with unstable percolation processes. Our data do not support a slow, homogeneous porous flow model for melt migration.

The olivine gabbros possess two foliations: a "podiform" foliation and a foliation formed by cataclastic processes. There are two possibilities for the formation of the podiform foliation: (1) mechanical rotation, flattening and corrosion of olivine during magmatic flow; or (2) injection of mafic melt into an en-echelon crack geometry located at the tip of a propagating dike. The cataclastic deformation observed in the gabbros is probably related to rifting of the EPR lithosphere by the Cocos-Nazca propagator. Metamorphic mineral assemblages indicate that static metamorphism of the mafic rocks occurred at temperatures of $400^{\circ}-500^{\circ} \mathrm{C}$. A lower temperature alteration $\left(220^{\circ}-\right.$ $420^{\circ}$ ) coincides with brittle deformation during rifting. Thus, it is not likely that the high dislocation densities recorded in the olivine grains from melt-impregnated dunites are a result of the later, low-temperature brittle shearing.

Brittle deformation during rifting is highly localized within the mantle gabbros. With the exception of sheared dunites at contacts, the harzburgites, dunites and troctolites found at Site 895 are practically devoid of cataclastic deformation; the gabbros and olivine gabbros appear to have accommodated most of the brittle deformation associated with the opening of the Hess Deep. This apparent strain localization within the gabbroic rocks indicates that the gabbros were weaker than the surrounding peridotite at the time of brittle deformation. The gabbros may have become relatively mechanically weak as a result of a larger number of cracks and pores in the gabbros (as rock strength decreases with increasing porosity). Alternatively, alteration of the gabbros, to products such as tremolite and chlorite, may have weakened these rocks relative to the surrounding ultramafic units.

\section{ACKNOWLEDGMENTS}

This work was supported by JOI/USSAC Grant number USSSP 147-207736. We thank Martha Daines and Jan Tullis for helpful reviews that substantially improved the manuscript.

\section{REFERENCES}

Avé Lallemant, H.G., and Carter, N.L., 1970. Syntectonic recrystallization of olivine and modes of flow in the upper mantle. Geol. Soc. Am. Bull., $81: 2203-2220$. 
Boudier, F., and Nicolas, A.. 1977. Structural controls on partial melting in the Lanzo peridotites. Bull,-Oreg. Dept. Geol. Miner. Ind., 96:63-78.

Chadam, J., Hoff, D., Merino, E., Ortoleva, P., and Sen, A., 1986. Reactive infiltration instabilities. J. Appl. Math, 36:207-221.

Ceuleneer, G., 1991. Evidences for a paleo-spreading center in the Oman ophiolite: mantle structures in the Maqsad area. In Peters, T., Nicolas, A. and Coleman, R.G. (Eds.), Ophiolite Genesis and Evolution of Oceanic Lithosphere: Dordrecht (Kluwer), 147-173.

Dick, H.J.B., 1977. Evidence of partial melting in the Josephine Peridotite. Bull.-Oreg, Dep. Geol. Miner. Ind., 96:59-62.

Dick, H.J.B., Bryan, W.B., and Thompson, G., 1981. Low-angle faulting and steady-state emplacement of plutonic rocks at ridge-transform intersections. Eos, 62:406

Dick, H.J.B., Meyer, P.S., Bloomer, S., Kirby, S., Stakes, D., and Mawer, C. 1991. Lithostratigraphic evolution of an in-situ section of oceanic Layer 3. In Von Herzen, R.P., Robinson, P.T., et al., Proc. ODP, Sci. Results, 118: College Station, TX (Ocean Drilling Program), 439-538.

Durham, W.B., Goetze, C., and Blake, B., 1977. Plastic flow of oriented single crystals of olivine, 2 . Observations and interpretations of the dislocation structures. J. Geophys. Res., 82:5755-5770.

Fedotov, S.A., 1978. Ascent of basic magmas in the crust and the mechanism of basaltic fissure eruptions. Int. Geol. Rev., 20:33-47.

Francheteau, J., Armijo, R., Cheminée, J.L., Hekinian, R., Lonsdale, P.F., and Blum, N., 1990. 1 Ma East Pacific Rise oceanic crust and uppermost mantle exposed by rifting in Hess Deep (equatorial Pacific Ocean). Earth Planet. Sci. Lett., 101:281-295.

Green, H.W., II, and Radcliffe, S.V., 1972. Dislocation mechanisms in olivine and flow in the upper mantle. Earth Planet. Sci. Lett., 15:239-247.

Gueguen, Y., and Darot, M., 1982. Upper mantle plasticity from laboratory experiments. Phys. Earth Planet. Inter., 29:51-57.

Hirsch, P.B., Howie, A., Nicholson, R.B., Pashley, D.W., and Whelan, M.J. 1965. Electron Microscopy of Thin Crystals: London (Butterworths).

Ildefonse, B., Nicolas, A., and Boudier, F., 1993. Evidence from the Oman ophiolite for sudden stress changes during melt injection at oceanic spreading centers. Nature, 366:673-676.

Johnson, K.T.M., and Dick, H.J.B., 1992. Open system melting and temporal and spatial variation of peridotite and basalt at the Atlantis II fracture zone. J. Geophys. Res., 97:9219-9241.

Johnson, K.T.M., Dick, H.J.B., and Shimizu, N., 1990. Melting in the oceanic upper mantle: an ion microprobe study of diopsides in abyssal peridotites. J. Geophys. Res., 95:2661-2678.

Karson, J.A., Hurst, S.D., and Lonsdale, P.F., 1992. Tectonic rotations of dikes in fast-spread oceanic crust exposed near Hess Deep. Geology, 20:685-688

Karson, J.A., Thompson, G., Humphries, J.M., Edmond, W.B., Bryan, W.B., Brown, J.R., Winters, A.T., Pockalny, R.A., Casey, J.F., Campbell, A.C. Klinkhammer, G., Palmer, R.J., Kinzler, R.J., and Sulanowska, M.M. 1987. Along axis variations in seafloor spreading in the MARK area. $\mathrm{Na}$ ture, 328:681-685.

Kelemen, P.B., and Dick, H.J.B., 1995. Focused melt flow and localized deformation in the upper mantle: juxtaposition of replacive dunite and ductile shear zones in the Josephine peridotite, SW Oregon. J. Geophys. Res., 100:423-438.

Kelemen, P.B., Whitehead, J.A.. Aharonov, E., and Jordahl, K.A., 1995. Experiments on flow focusing in soluble porous media, with applications to melt extraction from the mantle. J. Geophys. Res., 100:475-496.

Kirby, S.H., and Raleigh, C.B., 1973. Mechanisms of high-temperature, solid-state flow in minerals and ceramics and their bearing on the creep behavior of the mantle. Tectonophysics, 19:165-194.

Kohlstedt, D.L., Nichols, H.P.K., and Hornack, P., 1980. The effect of pressure on the rate of dislocation density recovery in olivine. J. Geophys. Res., 83:3122-3130.

Logan, J.M., Friedman, M., Higgs, N., Dengo, C., and Shimamoto, T., 1979. Experimental studies of simulated gouge and their application to studies of natural fault zones. Open-File Rep.-U.S. Geol. Surv., 79-1239:305343.
Lonsdale, P., 1988. Structural pattern of the Galapagos microplate and evolution of the Galapagos triple junction. J. Geophys. Res., 93:13551-13574.

Maaloe, S., 1981. Magma accumulation in the ascending mantle. J. Geol. Soc. London, 138:223-226.

Mackwell, S.J., Bai, Q., and Kohlstedt, D.L., 1990. Rheology of olivine and the strength of the lithosphere. Geophys. Res. Lett., 17:9-12.

McKenzie, D.P., 1984. The generation and compaction of partially molten rock. J. Petrol., 25:713-765.

Nicolas, A., 1986. A melt extraction model based on structural studies in mantle peridotites. J. Petrol., 27:999-1022.

, 1989. Structure of Ophiolites and Dynamics of the Oceanic Lithosphere: Dordrecht (Kluwer).

, 1990. Melt extraction from mantle peridotites: hydrofracturing and porous flow, with consequences for oceanic ridge activity. In Ryan, M.P. (Ed.), Magma Transport and Storage: Chichester (Wiley), 159-173.

Parmentier, E.M., and Schubert, G., 1989. Rift propagation. Geophys. Res. Lett., 16:183-186.

Phakey, P., Dollinger, G., and Christie, J., 1972. Transmission electron microscopy of experimentally deformed olivine crystals. In Heard, H.C., Borg, L.C., Carter, N.L., and Raleigh, C.B. (Eds.), Flow and Fracture of Rocks, Am. Geophy. Union, Geophys. Monogr., 16:117-138.

Pollard, D.D., 1987. Elementary fracture mechanics applied to the structural interpretation of dykes. In Halls, H.C., and Fahrig, W.F. (Eds.), Mafic Dyke Swarms. Geol. Assoc. Can., Spec. Pap., 34:5-24.

Quick, J.E., 1981. The origin and significance of large, tabular dunite bodies in the Trinity peridotite, northern California. Contrib. Mineral. Petrol., 78:413-422.

Rubin, A.M., 1993. Dikes vs. diapirs in visco-elastic rock. Earth Planet. Sci. Lett., 119:641-659.

Ryan, M.P., 1988. The mechanics and three-dimensional internal structure of active magmatic systems: Kilauea Volcano, Hawaii. J. Geophys. Res., 93:4213-4248

Salters, V.J.M., and Hart, S.R., 1989. The hafnium paradox and the role of garnet in the source of mid-ocean-ridge basalts. Nature, 342:420-422.

Scott, D.R., and Stevenson, D.J., 1986. Magma ascent by porous flow. J. Geophys. Res., 91:9283-9296.

Shipboard Scientific Party, 1993. Site 895. In Gillis, K., Mével, C., Allan, J., et al., Proc. ODP, Init. Repts., 147: College Station, TX (Ocean Drilling Program), 109-159.

Sleep, N.H., 1974. Segregation of a magma from a mostly crystalline mush. Geol. Soc. Am. Bull., 85:1225-1232.

1988. Tapping of melt by veins and dikes. J. Geophys. Res., 93:10255-10272.

Spence, D.A., and Turcotte, D.L., 1985. Magma-driven propagation of cracks. J. Geophys. Res., 90:575-580.

Spera, F.J., 1987. Dynamics of translithospheric migration of metasomatic fluid and alkaline magma. In Menzies, M.A., and Hawkesworth, C.J. (Eds.), Mantle Metasomatism: New York (Academic), 1-20.

Spiegelman, M., and Kenyon, P., 1992. The requirements for chemical disequilibrium during melt migration. Earth Planet. Sci. Lett., 109:611-620.

Suzuki, I., Anderson, O.L., and Sumino, Y., 1983. Elastic properties of a single-crystal forsterite $\mathrm{Mg}_{2} \mathrm{SiO}_{4}$, up to 1200K. Phys. Chem. Miner., 10:3846.

Timoshenka, S.P., and Goodier, J.N., 1934. Theory of Elasticity (3rd ed.): New York (McGraw-Hill).

Tullis, J., and Yund, R.A., 1987. Transition from cataclastic flow to dislocation creep of feldspar: mechanisms and microstructures. Geology, 15:606-609.

Date of initial receipt: 1 August 1994

Date of acceptance: 27 April 1995

Ms 147SR-022 